\title{
FACTORS AFFECTING SATISFACTION AND LOYALTY OF ONLINE TAXI-MOTOR PARTNERS
}

\author{
Luvy Mayanda*)1, Hari Wijayanto**), and Istiqlaliyah Muflikhati***) \\ *) School of Business, Bogor Agricultural University \\ SB IPB Building, Pajajaran Road, Bogor, Indonesia 16151 \\ ${ }^{* *}$ Department of Statistic, Faculty of Mathematics and Natural Sciences, Bogor Agricultural University \\ Jl. Meranti Wing 22 Level 4, Dramaga, Bogor, Indonesia 16680 \\ ${ }^{* * *}$ Department of Family and Consumet Sciences, Faculty of Human Ecology, Bogor Agricultural University \\ Jl. Lingkar Akademik, Dramaga, Bogor, Indonesia 16680
}

\begin{abstract}
A growing number of online motorcycle taxi is impacting a greater competition in its business to the extent that a business partner of the motorcycle taxi contributes a significant portion in the business. The purpose of this journal was to observe the influence of satisfaction level on partner loyalty in online taxi-motor application company in Bekasi city. The levels of satisfaction and loyalty of the business partner were measured by using CSI and CLI methods. 125 business partners, operating in Bekasi, became the respondents in this analysis based on Slovin method with $10 \%$ error margin. SEM methods were utilized to analyze the influence of the business partner characteristics on the level of satisfaction and the impact of level of satisfaction on business partner loyalty. In addition, IPA was used to analyze the significant attributes of business partner's level of satisfaction. CSI and CLI findings show that the business partners are within the satisfactory level and high loyalty towards its current partnership. SEM analysis reveals that there is a strong influence between the level of partner's satisfaction and loyalty. Better provision of trip rates has become a significant indicator for business partner during the partnership process which was examined by IPA method.
\end{abstract}

Keywords: online transportation, satisfaction index, loyalty index, IPA, CSI

\begin{abstract}
Abstrak: Pertumbuhan bisnis ojek online yang tinggi berdampak pada persaingan yang ketat pada bisnis ini sehingga seorang mitra ojek memiliki peran yang sangat penting dalam bisnis. Penelitian ini bertujuan untuk melihat pengaruh tingkat kepuasan terhadap loyalitas mitra pada perusahaan aplikasi ojek online di Kota Bekasi. Analisis tingkat kepuasan dan loyalitas mitra dengan menggunakan metode CSI dan CLI. Mitra yang menjadi responden pada penetian ini sebanyak 125 orang yang beroperasi di wilayah Kota Bekasi berdasarkan metode Slovin dengan margin error 10\%. Menganalisis pengaruh karakteristik mitra terhadap kepuasan dan pengaruh kepuasan terhadap loyalitas mitra dengan menggunakan metode SEM. Analisis tingkat kepentingan atributatribut kepuasan mitra menggunakan metode IPA. CSI dan CLI mengkategorikan mitra pada level puas dan loyalitas tinggi terhadap kemitraan saat ini. Analisis SEM menyatakan adanya pengaruh yang signifikan antara tingkat kepuasan mitra dengan loyalitas mitra. Indikator penetapan tarif perjalanan yang lebih baik merupakan indikator yang sangat penting bagi mitra dalam proses kemitraan yang dihasilkan oleh metode IPA.
\end{abstract}

Kata kunci: transportasi online, indeks kepuasan, indeks loyalitas, IPA, CSI

\footnotetext{
${ }^{1}$ Corresponding author:

Email: luvymayanda@gmail.com
} 


\section{INTRODUCTION}

Based on the high rate of technological growth in the world as reflected in the World Economic Forum report dated to August 1, 2016, the most valuable public companies today are technology-based companies. Apple, Alphabet, Microsoft, Amazon, and Facebook are selected as the top five most valuable companies followed by one oil and gas company, Exxon Mobil, in the sixth position. The Association of Indonesian Internet Service Providers (APJII), in cooperation with Communication Studies Center of University of Indonesia (PUSKAKOM UI) (2014) stated in its research in 2014 that the number of internet users in Indonesia in 2014 reached 88.1 million, and the internet usage in Indonesia is dominated by mobile phone as a tool with the number of usage $85 \%$ of the total internet users in Indonesia.

Online transportation business using technological based mobile phone application is a new form of business model that can capture the opportunities. In contrast to public transportation modes in other countries, Indonesia has a uniqueness with a widely available transportation mode of motorcycle called the motorcycle taxi. This uniqueness is able to be utilized by Go-Jek company as the initiator of the first onlinebased service provider of motorcycle taxi transportation in Indonesia. Partnership system was adopted as the business strategy undertaken by this company i.e. a strategy undertaken by two or more parties within a certain timeframe to achieve mutual benefit with the principle of mutual need and exaggeration (Hafsah, 1999). The online motorcycle taxi company is targeting the market of application service users inhabiting Jabodetabek as $60 \%$ of the largest internet users in Indonesia is located in Java with the largest coverage in Jabodetabek. As a part of Jabodetabek, Bekasi is one of the largest internet service users in West Java. In addition, Bekasi has a high population density in which the total population is 2,523,032 people (BPS Bekasi, 2014) with the city area of merely $210.49 \mathrm{~km}^{2}$. The researchers are interested in conducting this research in Bekasi due to its highest predicate of Consumer Price Index (CPI) for transportation, communications and services sectors and of City's Minimum Wage (UMK) in 2016 and 2017 compared to other areas in Jabodetabek.

Following the business development and good response from the market, other companies offer the same business in Indonesia such as GRAB and UBER which initially concentrate only on online business of fourwheeled drive modes. Hence, the level of competition in online motorcycle taxi business tightens. The partnership strategy used in this business allows the partners to be the most important pillars in the online motorcycle business, so one of the strategies undertaken by the application service provider companies is to conduct partner hiring process by hijacking method from the partner of the competitor company.

Investments from the investors can bring income capital to the company influenced by the good trademark of the company (Crass et al. 2016). PT GoJek Indonesia opens the recruitment of new drivers by special invitation via short message. This recruitment is specifically designed to attract potential drivers from competitor companies, such as GrabBike and UberBike (Metrotvnews, 2016). This aims to accelerate partner adaptation and business growth, yet this strategy will disrupt the performance of its competitors. Kotler and Gery (2006) define satisfaction as someone's feeling of pleasure or disappointment which emerges after comparing the performance of the product (outcome) received and expected.

Intensive granting strategies and company policies for its partners are often conducted by the company due to the importance of partner existence, yet some of the strategies employed cause conflict between the online motorcycle taxi partners and the service provider company. Rights and obligations of the parties are stated in the partnership agreement or determined by law (Melyanti, 2014). The masses demonstrated by shouting jargons and showing posters, saying 'We are drivers, not dairy cows', 'delete performance systems', 'fight back' and others (Detik News, 2016). Demonstrations occurring among partners illustrate that the level of satisfaction and loyalty of partners is important to maintain the company's brand image. The company operations are controlled by reducing the cost of new partner recruitment and training, which can also affect the company's profits. Parasuraman and Grewal (2000) stated in their journal that consumer loyalty is the main topic most commonly examined in literature of services. Minoque (2016) suggests that there is a correlation between employee engagement, employee satisfaction, and higher turnover rates. Pooja and Pradev (2007), in their research, argue that satisfaction has a significant influence on business relationships between companies and consumers. 
The objectives of this research were to: analyze the level of satisfaction and loyalty of online motorcycle taxi business; analyze the influence of the satisfaction level of online motorcycle taxi partners on their loyalty, and identify the importance of the attributes influencing the satisfaction level of the online motorcycle taxi partners. The research was conducted to identify the factors that influence the satisfaction level of the online motorcycle taxi and to analyze the influence of the satisfaction level of online motorcycle taxi partners on their loyalty in Bekasi. The loyalty of online motorcycle taxi partners is expected to improve the service to online motorcycle taxi consumers.

\section{METHODS}

The research data were taken from April 2017 to August 2017 with Go-Jek, Grab Bike and Uber Bike online motorcycle taxi partners operating in Bekasi as the research respondents. The data source of this study was taken by using primary data, obtained or collected directly by researchers from the sources (Sumarwan, 2014). The data used in this research were obtained by conducting direct interviews to the online motorcycle taxi partners in Bekasi using a structured questionnaire covering the characteristics of respondents i.e. age, education, number of dependents, origin, and marital status.

The sampling technique done by this research was non-probability sampling technique i.e. a sampling technique without opportunities. Purposive sampling by stratification was utilized based on the service provider application companies. The selection of respondents was based on the number of different partners in the research population and restricted to partners using only one application in their operations. The population character is from the dynamic partner movement and the tendency to approach the demand in the center of the crowds in Bekasi such as stations, malls, terminals, and large housing, so that the respondents were chosen at these locations. Determination of the number of respondents in this research was 125 consisting of 31 Go-Jek partners, 50 Grab Bike partners and 44 Uber Bike partners measured by using Slovin method with a margin error of $10 \%$ and the estimated population of operating respondents as many as 10,000 with the following details: 2,500 for Go-Jek, 4,000 for Grab Bike, 3,500 for Uber.
The number of qualified sample sizes in accordance with what is proposed by several researchers such as Fraenkel and Norman (1993) suggesting that the minimum sample size for descriptive research is 100 . Processing techniques and data analysis in this study are: Customer Satisfaction Index (CSI) was used to examine the overall satisfaction level of online motorcycle taxi partners with an approach that takes into account the importance of the determined attributes, so that it can assist in the process of internal performance improvement and with the equation:

$\mathrm{CSI}=\frac{\sum_{k=1}^{r} W S_{k}}{H S} \times 100 \%$

Customer Loyalty Index (CLI) was used to measure the loyalty level of partners towards the companies providing online transportation services. Interpretation of CSI and CLI values was based on Simamora (2004), $0 \leq \mathrm{X}<20 \%$ interpreted to be very dissatisfied, $20 \% \leq \mathrm{X}<40 \%$ interpreted to be not satisfied, $40 \%$ $\leq \mathrm{X}<60 \%$ interpreted to be quite satisfied, $60 \% \leq \mathrm{X}$ $<80 \%$ interpreted to be satisfied, and $60 \% \leq \mathrm{X}<80 \%$ interpreted to be very satisfied.

Structural Equation Modeling (SEM) by using lisrel program was used to analyze the influence between the satisfaction attributes of online motorcycle taxi partner and analyze the influence of partner satisfaction on loyalty thoroughly. Prihanto (2013) conducted a research on the influence of customer satisfaction factors by using IPA, CSI CLI and SEM methods on customer loyalty which can show the effect of satisfaction factors on customer satisfaction and on customer loyalty.

The components used in the general model of SEM consisted of non-free latent variables of partner satisfaction and loyalty, while the latent free variables consisted of tangible, reliability, responsiveness, assurance, and empathy dimensions that can measure satisfaction (Kartika et al. 2015) with the total of 16 attributes are illustrated in Table 1.

Importance and Performance Analysis (IPA), Data processing with IPA method was used to analyze the expectation level of online motorcycle taxi partner on the attributes of partnership between online motorcycle taxi partners and online application provider companies. 
Table 1. Latent variables and indicator variables

\begin{tabular}{|c|c|c|}
\hline Latent Variable & Indicator Variable & \\
\hline \multirow[t]{3}{*}{ Tangible } & Availability of work equipment (helmet and jacket) & $\mathrm{T} 1$ \\
\hline & Quality of Partner's Equipment & $\mathrm{T} 2$ \\
\hline & Quality of online partner application & $\mathrm{T} 3$ \\
\hline \multirow[t]{3}{*}{ Reliability } & Quality of contact center service & $\mathrm{R} 1$ \\
\hline & Determination of tariffs in accordance with operational costs & $\mathrm{R} 2$ \\
\hline & Availability of distribution orders to partners well & R3 \\
\hline \multirow[t]{3}{*}{ Responsiveness } & The quality of the app company response to partner complaints & RE1 \\
\hline & The speed of the app company response to partner complaints & RE2 \\
\hline & Partner problem solving quality & RE3 \\
\hline \multirow[t]{4}{*}{ Assurance } & Friendliness and company propriety towards partners & A1 \\
\hline & Availability of good bonus incentive system & A2 \\
\hline & Availability of long-standing partnership enhancement & A3 \\
\hline & Availability of partner health insurance & A4 \\
\hline \multirow[t]{3}{*}{ Empathy } & The company app sensitivity on the partners' desire & E1 \\
\hline & Responses and provision on partner's needs before being asked & E2 \\
\hline & Flexibility of the company in handling partner problems & E3 \\
\hline Satisfaction & Partner satisfaction on application provider company & Y1 \\
\hline \multirow[t]{2}{*}{ Loyalty } & The willingness of partners not to move to other online application providers & $\mathrm{Y} 2$ \\
\hline & The willingness of partners to recommend application provider company to others & Y3 \\
\hline
\end{tabular}

\section{RESULT}

\section{Partner Characteristics}

The demographic characteristics of partners examined in this study were the age, education and number of dependents as illustrated in Table 2. Chien et al. (2017) observed the relationship of age group, educational level, income level, area of residence, and profession on satisfaction. The first characteristic is age classified into three groups i.e. adolescents (18-25 years) by 46 partners or $37 \%$, adults (26-45 years) by 78 partners or $62 \%$, and elderly (53 years) by 1 partner or $1 \%$. Major Labor Law of the Republic of Indonesia no. 13/2003 categorizes all age groups of partners currently belong to the category of labor or productive age considered to work and are able to work if there is no job demand with age ranges between 15 years to 64 years, so it can affect the satisfaction (Morgan and Rego, 2006). The second characteristic is education. Based on education level existing in Indonesia, there are four levels of education that exist in the research respondents i.e. junior high school (SMP) by 3 partners or 2\%, Senior High School (SMA) by 95 partners or $76 \%$, Diploma by 16 partners or $13 \%$, and Undergraduate by 8 partners or $6 \%$.
The majority of partners are currently in the middle and higher education groups by $95 \%$, which is considered to have a core competence in spiritual attitudes, social attitudes, knowledge and sufficient skill (Permendikbud 2014). Seider et al. (2005) and Capraro et al. (2003) revealed that the level of education and the number of dependents did not have a significant effect on customer satisfaction. The next characteristic is the presence or absence of dependents such as the wife or children who are the responsibility of the partner during the survey. Table 2 shows $54 \%$ of partner respondents at the time of the survey did not have dependents, and $46 \%$ of the partners had dependents. The last characteristic is the marital status of the partner. The survey was divided into two groups: married partners by 64 partners or $51 \%$ or were married and partners who had never married by 58 partners or $47 \%$ of the sample amounts.

\section{Analysis on Partner Satisfaction and Loyalty Levels}

The rate of satisfaction index of the online motorcycle taxi driver in Bekasi as illustrated in Figure 1 shows the CSI value obtained from this research is 68 , indicating that the partners are satisfied in partnering with the application provider company. All companies currently have the nature of partnership pattern joined subordinately or also called as subordinate union of 
partnership (Sulistiyani, 2004). The research attribute that has the highest satisfaction score is the quality of application for partners available from the company as the current application can be used easily and nearly no problems caused by the application. Satisfaction is influenced by the workplace environment, the worker's environment and the work itself (Morales, 2015). The value of CSI in this study separated per operator shows the level of satisfaction of Go-jek partners of 75 which means that partners are satisfied with the current partnership. In the highest attribute value of satisfaction on the hospitality and courtesy attributes of the online motorcycle application company to its partners, Grab Bike has a CSI value of 64 which means that partners are satisfied with their current partnership. The attribute that has the greatest value is that the quality of apps for partners available from the company can be used easily and rarely experiences errors caused by Grab applications. The value of CSI Uber bike is 67 which means that partners are satisfied with the current partnership. The highest attribute value with satisfaction is the quality of apps for partners available from the company that can be used easily and rarely experiences errors caused by current applications. The results obtained for Grab and Uber partners show that innovations in online applications have a positive and significant impact on customer satisfaction and brand loyalty (Krom, 2015).

The value of the partner loyalty index measured in this study is divided into two indicators: partners are willing to remain partners in the current online motorcycle application company and partners are willing to recommend the current online motorcycle application company to colleagues or partner relatives. Figure 2 shows the CLI value for all partners is 80 , indicating that partners have high loyalty, so they are willing to stay in partnership with the current application provider company and are willing to recommend the company's current application to colleagues or partner relatives. Go-Jek has the highest CLI value of 85 , and this value states the willingness to stay in partnership with the company's current application provider and to recommend the company's current application to colleagues or partner relatives. This result is in line with the high CSI value of previous Go-Jek partners with the highest attributes of hospitality and courtesy from the online motorcycle taxi company to its partners. Although Go-Jek has a partnership pattern similar to the others, they do not implement a much more complicated scoring system than any other company.

Table 2. Partner demographic characteristics

\begin{tabular}{|c|c|c|c|c|c|c|c|c|c|}
\hline & \multirow{3}{*}{ Characteristics } & \multicolumn{8}{|c|}{ Partner } \\
\hline & & \multicolumn{2}{|c|}{ Go-Jek } & \multicolumn{2}{|c|}{ Grab Bike } & \multicolumn{2}{|c|}{ Uber Bike } & \multicolumn{2}{|c|}{ Total } \\
\hline & & $\mathrm{n}$ & $\%$ & $\mathrm{n}$ & $\%$ & $\mathrm{n}$ & $\%$ & $\mathrm{n}$ & $\%$ \\
\hline Partner & & 31 & 25 & 50 & 40 & 44 & 35 & 125 & 100 \\
\hline \multirow[t]{2}{*}{ Age } & Adolescents & 9 & 29 & 21 & 42 & 16 & 36 & 46 & 37 \\
\hline & Adults & 22 & 71 & 29 & 58 & 28 & 64 & 79 & 63 \\
\hline \multirow[t]{3}{*}{ Education } & Elementary & 0 & 0 & 0 & 0 & 3 & 7 & 3 & 2 \\
\hline & Intermediate & 23 & 74 & 41 & 82 & 31 & 70 & 95 & 76 \\
\hline & Advanced & 8 & 26 & 9 & 18 & 10 & 23 & 27 & 22 \\
\hline \multirow[t]{2}{*}{ Dependent } & Yes & 14 & 45 & 29 & 58 & 25 & 57 & 68 & 54 \\
\hline & No & 17 & 55 & 21 & 42 & 19 & 43 & 57 & 46 \\
\hline \multirow[t]{2}{*}{ Marital Status } & Married & 17 & 55 & 24 & 48 & 23 & 52 & 64 & 51 \\
\hline & Single & 14 & 45 & 26 & 52 & 21 & 48 & 61 & 49 \\
\hline
\end{tabular}

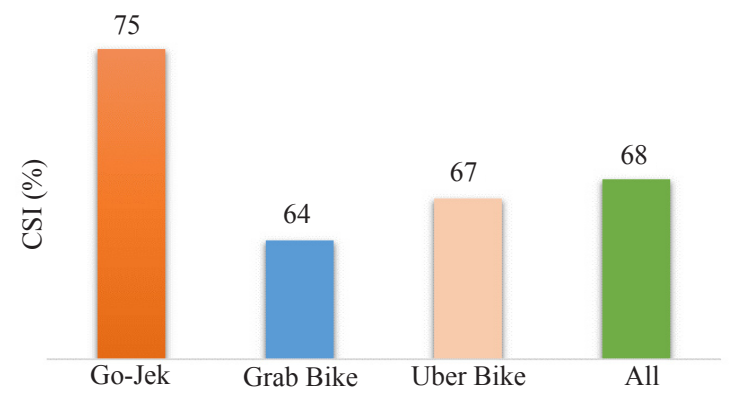

Figure 1. CSI of Partnership

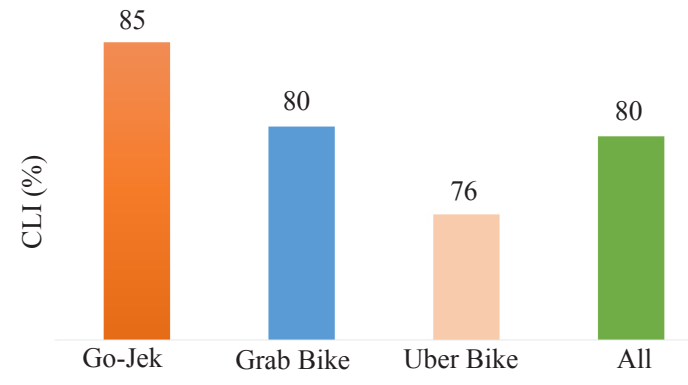

Figure 2. CLI of partnership 
Analysis on the Influence of Satisfaction on Partner Loyalty

SEM analysis in this research was started with goodness of fit testing on the research model by using several goodness of fit criteria, such as Root Mean Square Error Of Approximation (RMSEA) (Chen et al. 2008), Goodness of Fit Index (GFI) (Joreskog, 1973), Adjusted Goodness of Fit (AGFI), Incremental Fit Index (IFI) (Bollen, 1989), Normed Fit Index (NFI) (Brown and Cudeck, 1993) and Comparative Bentler Fit Index (CFI) with the conclusion of good fit research models as seen in Table 3. Therefore, the hypothesis testing of model theory in this research can be continued to the next step.

Table 3. Goodness of fit testing data

\begin{tabular}{lcc}
\hline Goodness-of-Fit & Standard & Result \\
\hline RMSEA & $\leq 0.08$ & 0.074 \\
GFI & $>0.90$ & 0.94 \\
AGFI & $>0.90$ & 0.91 \\
IFI & $>0.90$ & 0.96 \\
NFI & $>0.90$ & 0.91 \\
CFI & $>0.90$ & 0.96 \\
\hline
\end{tabular}

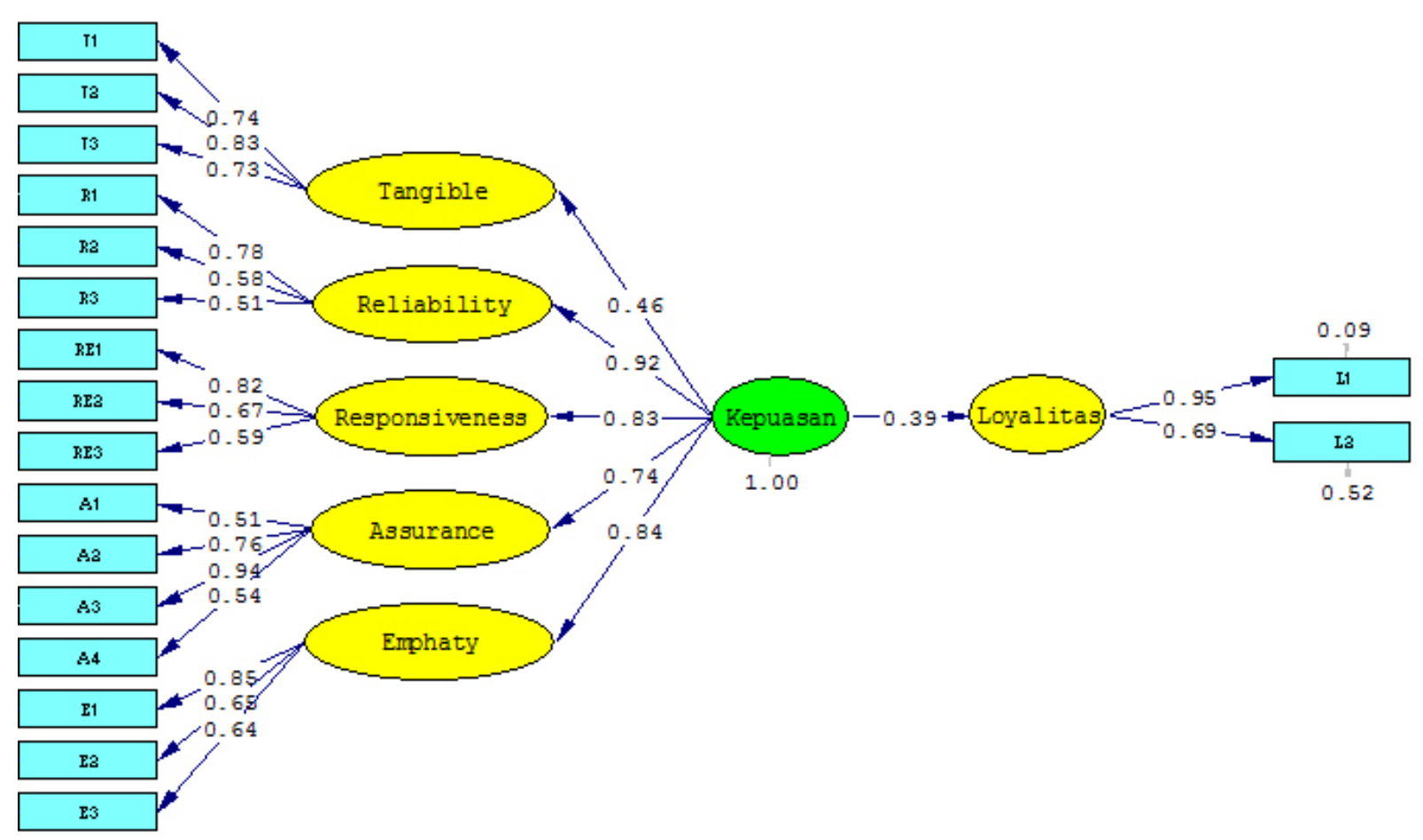

Chi-Square $=184.00, d f=110, P-$ value $=0.00001$, RMSEA $=0.074$

Figure 3. Path diagram of loading factor SEM research
The parameter path diagram illustrating the load factor in this research can be seen in Figure 3. The values of load factor in the diagram illustrate the contribution of each variable in which the largest load factor value is the most contributing or influencing factor from the indicator variables in forming latent variables.

The $t$-value in this study is shown to have a value greater than 1.96 , indicating that the validity of each construct indicator or latent model variables used were good (Ferdinand, 2002). Besides, the value can be interpreted that the construct indicator and its latent variables have significant influence (Ghozali and Hengky, 2012). The $\mathrm{t}$-value of the SEM calculation illustrating the influence of partners' satisfaction on loyalty is $9.62>1.92$, so that the resulting in a conclusion that partner satisfaction has a significant influence on partner loyalty. This is in line with previous studies which found that quality services have a positive and significant impact on customer satisfaction (Chen YH and Stuart, 2007), while quality service does not directly affect loyalty (Bakti and Sumaedi, 2012). The quality dimension that has the greatest contribution or influence to partner satisfaction is reliability compared to other quality dimensions, where the reliability is measured by three indicator variables, and the indicator that has the biggest contribution is the quality of contact center service of the online motorcycle taxi business (R1). 
Identification of Attribute Importance Levels Influencing the Partner Satisfaction Level

Importance and Performance Analysis (IPA) shows the importance of each partner satisfaction indicator in Figure 4. Indicator R2 is in the first quadrant, concentrate here, which means the travel rates set by the online motorcycle taxi service provider is a very important indicator for partners. However, they have not been established well by the company resulting in dissatisfaction of the partners. Indicators in quadrant II, (T1), (T2), (T3), (A1), (A2), (R1), (R3), and (RE2) state that the above indicators are important to be fulfilled by online motorcycle Operator Company for partners; therefore, their performance should be maintained. Quadrant III states that the indicators (A3), (A4), (RE3), (E1), (E2) and (RE1) indicate that they have low or less important priorities for partners, and it is appropriate for companies to fulfil them ordinarily. The last indicator (E3) in quadrant IV indicates that the indicator has low priority for the online motorcycle taxi partner, yet the company has implemented it excessively.

\section{Managerial Implications}

The results of this study is expected to provide benefits to application provider companies to improve competitiveness in online motorcycle taxi industry. The online transportation industry nowadays is not only as a complement to the existing transportation, but also a replacement of the existing transportation industry (Anders and Iwaona, 2016). The intensity of competition in this industry is very high which is evident in the balance of strength between companies, diverse strategies, and the high role of suppliers in researches of partnerships (Porter, 2008). In reference to this matter, the loyalty of partners is very important to be noted by the company's application provider as an enhancer of competitiveness. In line with SEM analysis result of this research, the partner loyalty can be increased by increasing partner satisfaction at every dimension of existing quality in which dimension of reliability with its attributes i.e. improving contact center quality, charge establishment, and order distribution becomes the main dimension to be enhanced to partners. This is because the dimension has a great influence on partner satisfaction. When service takes place from time to time, it is necessary to motivate the workers as the results of the service have an effect on customer satisfaction (Briggs et al. 2014). Indicators of quality dimensions, other than reliability that has a major influence on partner satisfaction, are the company's sensitivity to partner conditions, the quality of responses from partner complaints, the level of partnership status, and the quality of the work equipment provided to partners such as help and jackets. Companies can increase service activities by training employees who have benefits to the social environment both inside and outside the company (Wayuningsih, 1999), so that partner satisfaction is expected to increase.

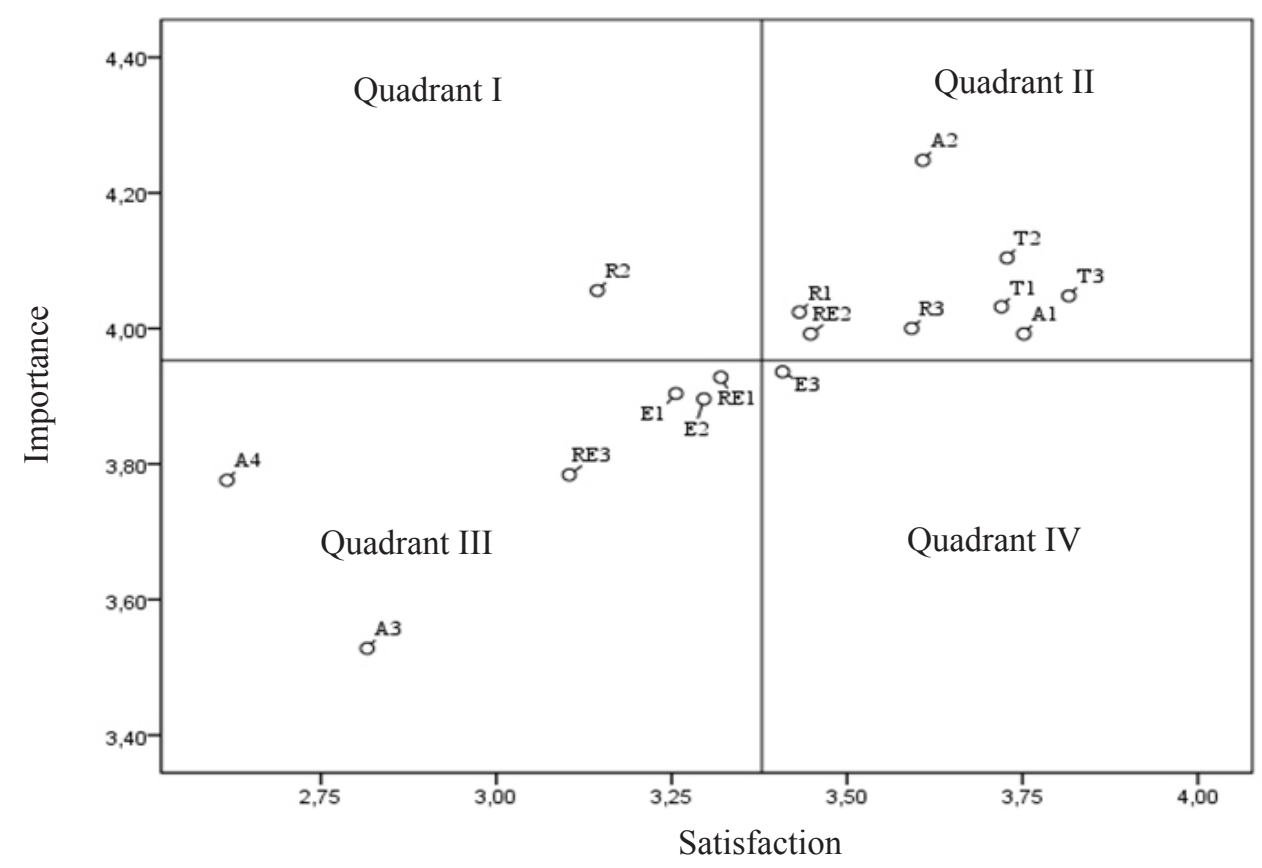

Figure 4. Importance and performance analysis of partnership 
IPA analysis as a method that describes the importance of each partner satisfaction indicator in Figure 8 shows that the $\mathrm{R} 2$ indicator i.e. the travel rates set by online motorcycle taxi service provider is a very important indicator for the partners, yet it is not well defined by the company, causing partner dissatisfactions. High level of partner satisfaction is expected to give online transportation consumers an alternative based on convenience in using the provided online transportation service (Hannah, 2015). Prospective partners can also use this research to illustrate the degree of satisfaction and loyalty of partners on existing partnerships before choosing to join an online motorcycle taxi partnership. The value of CSI and CLI can be used as a reference to prospective partners in choosing an application company to get satisfaction in partnering. Go-Jek becomes the company with the highest CSI and CLI values compared to the others. Uber Bike loyalty is seen to be the lowest, in addition to low travel charge due to lacking of fulfillment of partner indicator which is very important to the satisfaction i.e. the quality of solving partner's problems from the online motorcycle taxi application company. Grab Bike has the lowest satisfaction, yet it has high loyalty because it has a better rate than Uber Bike and the number of bonus programs associated with loyalty such as bonuses obtained by leaving other applications or achieving certain work standards.

Therefore, the determination of travel rates must also be considered by the prospective partners when they decide to do the partnership, in addition to checking the service from the application company through the contact center in serving the current partner. Hasan (2009) stated that customer satisfaction does not necessarily indicate the customer loyalty as there is one condition where the customer has low loyalty despite high satisfaction which is classified as Defector (crossing), Failure (low satisfaction and low loyalty) and Forced Loyalty (low satisfaction but high loyalty) and Success (high loyalty and high satisfaction).

The limitations of this study were the restricted time of research, the unavailability of data on the population of partners both from companies and governments acting as regulators, and unavailable references of research journals on online transport partnerships until the results obtained as many researchers concentrated on applications and online motorcycle taxi transportation users.

\section{CONCLUSIONS AND RECOMMENDATIONS}

\section{Conclusions}

The current partnership pattern is subordinate resulting in a CSI level of partners at a satisfactory level with a value of 68 . Go-Jek partners have a CSI value of 75 and are the highest compared to Grab bike, 64, and Uber bike, 67. CLI score of 80 of the partners placed partner loyalty at a high level, so that they are willing to stay in partnership with the current application provider company and willing to recommend current partnerships to colleagues or relatives to join. The CLI on Go-Jek is 85 as the CSI value being the highest compared to the others. Hence, the position is at a very loyal level to the current partnership. Although all three partnerships are similar in nature, Go-Jek partners feel the hospitality and courtesy of the current partnership, and Go-Jek does not apply complicated rules in partnership scoring systems compared to others.

The level of partner satisfaction to partner loyalty in this research has a significant influence on the dimensions of reliability as the most influential dimension to partner satisfaction, and attributes that are parts of the dimensions of reliability are the quality of contact center service, established travel rates, and order distribution made by the company application provider.

The result of IPA analysis shows that the indicator that has the highest importance but not yet well defined is the indicator of reliability of rate establishment by the application company. Therefore, the partners hope that the established rate can be reviewed to increase the satisfaction and loyalty level of the partners.

\section{Recommendations}

The recommendation for further research is to examine the effects of demographic characteristics, other than the origin, age, number of dependents and education on the level of partner satisfaction. Establishing other indicators or patterns of partnership that have not been studied in this research is expected to expand the satisfaction analysis of partnership loyalty as the relationship of satisfaction and loyalty has the potential to change according to the life cycle of consumers (Kumar et al. 2013). 


\section{REFERENCES}

APJII, PUSKAKOM UI. 2014. Profil Pengguna Internet di Indonesia 2014. Jakarta:APJII dan PUSAKAKOM UI

[BPS Bekasi]. Badan Pusat Statistik Kota Bekasi 2014. Bekasi: BPS Kota Bekasi

Kemendikbud. 2014. Peraturan Kementrian Pendidikan dan Kebudayaan no. 59. 2014 tentang kurikulim pendidikan sekolah menengah atas (SMA/MA). Jakarta: Kemendikbud.

Metrotvnews. 2016. Alasan Driver Grab Pindah Ke Go-Jek. http://news.metrotvnews.com/ $\mathrm{read} / 2016 / 04 / 22 / 517724 /$ alasan-driver-grabpindah-ke-go-jek [12 Desember 2016].

Anders HH. Iwona MW. 2016. Transaction cost and sharing economy. INFO 18(1): 1-15. https://doi. org/10.1108/info-09-2015-0044

Bakti IGMY, Sumaedi, S. 2012. The empirical study of public transport passengers' behavioral intentions: the roles of service quality, perceived sacrifice, perceived value, and satisfaction (Case Study: Paratransit passengers in Jakarta, Indonesia)", International Journal for Traffic and Transport Engineering. Emerald Group Publishing Limited 2(1):406-407.

Bentler PM. 1990. Comperative fit indexes in structural models. Psychological Bulletin107(2):238-246.

Bollen KA. 1989. A new incremental fit index for general structural equation models. Sociological Methods and Research 17(3): 303-316.

Briggs E, Landry TD, Daugherty PJ. 2014. A framework of satisfaction for continually. Journal of Business \& Industrial Marketing 31(1):112-122. https:// doi.org/10.1108/JBIM-06-2014-0125

Brown MW, Cudeck R. 1993. Alternative Ways of Assessing Model Fit, in Testing Structural Equation Models. Newbury Park: Sage Publication.

Capraro A J, Broniarczyk S, Srivastava RK. 2003. Factors influencing the likelihood of customer defection: the role of consumer knowledge. Journal of the Academy of Marketing Science 31(2):75-164. https://doi. org/10.1177/0092070302250900.

Chen F, Curan PJ, bollen KA, Kirby J, Paxton P. 2008. An empirical evaluation of the use fixed cutoff points in rmsea test statistic in structural equation models. Sociol Methods Reseach 36(4): 462-494
Chen YH, Stuart B. 2007. Initial trust and buyer online behavior. Journal Industrial Management dan Data Systems 107(1):21-36

Chien CC, Ching CH, Hua HM, Yen LS, Yong Z. 2017. Exploring the relationships among campers' leisure motive, satisfaction and campsite service innovation. International Journal of Organization Innovation 10(2): 220-232.

Crass D, Czarnitzki D, Toole AA. 2016. The dynamic relationship between investments in brand equity and firm profitability:evidence using trademark registrations. Working Paper 2016-1.

Detiknews. 2016. Ribuan Driver Demo Di Kantor Gojek Lalin Kemang Jaksel Macet Parah. https:// news.detik.com/berita/d-3312016/ribuan-driverdemo-di-kantor-gojek-lalin-kemang-jakselmacet-parah [15 Desember 2016].

Ferdinand A. 2002. Structural equation modeling dalam penelitian manajemen aplikasi model-model rumit dalam penelitian untuk tesis magister dan doctor [tesis]. Semarang (ID):Universitas Diponogoro.

Fraenkel JR, Norman EW. 1993. How to design and evaluate research in education. Journal of Management Research 3(1):124-126.

Ghozali I, Hengky L. 2012. PLS Konsep, Teknik dan Aplikasi Menggunakan Program SmartPLS 2.0 M3. Semarang: Universitas Diponegoro

Hafsah MJ. 1999. Kemitraan Usaha. Jakarta: Pustaka Sinar Harapan

Hasan A. 2009. Marketing Edisi Baru. Yogyakarta: Media Pressindo

Joreskog KG. 1973. A general method for estimating a linier structural equation system, in structural equation models in the social sciences. Sweden: Universitas Uppsala

Kartika PA, Rita N, Djamaludin MD. 2015. Customer satisfaction and loyality of a franchise product evidence from Nasi Bebek Ginyo Restauran Jakarta. Indonesian Journal of Business \& Entrepreneurship 1(1):42-50.

Kotler P, Gery A. 2006. Principles of Marketing: Eleventh Edition. New Jersey: Pearson Prentice Hall

Krom I. 2015. Global online entrepreneurship and the impact of innovation on brands loyality. EMAJ: Emerging Markets Journal 5(2): 90-101. doi:https://doi.org/10.5195/emaj.2015.90

Minoque J. 2016. The effect of poor employee satisfaction on patient satisfaction in acute care [desertation]. NewYork: Utica Collage 
Melyanti IM. 2014. Pola kemitraan pemerintah, civil society, dan swasta dalam program bank sampah di Pasar Baru Kota Probolinggo. Jurnal Kebijakan dan Manajemen Publik 2(1)

Morales PE. 2015. An empirical study on the significanceof religiosity and spirituality for job satisfaction in public service [desertasi]. Meryland: University of Baltimore.

Morgan NA, Rego LL. 2006. The value of different customer satisfaction and loyality metrics in predicting business performance. Journal Marketing Science 25(5):426-439.

Parasuraman A, Grewal. 2000. The impact of technology on the quality-value-loyalty chain: a research agenda. Journal of the Academy of Marketing Science 28: 168. https://doi. org/10.1177/0092070300281015.

Pooja P, Pradeep AK. 2017. Anempirical study of factors influencing job satisfaction. Indian Journal of Commerce and Management Studies
8(3):96-105.

Porter M. 2008. Competitiveness Strategy. Tanggerang: Karisma Publishing Group

Prihanto A. 2013. Analisis kepuasan dan loyalitas konsumen korporat untuk acara M.I.C.E. terhadap kualitas pelayanan hotel HSTH [tesis]. Bogor: IPB.

Robbins S. Judge. 2008. Prilaku Organisasi, Edisi duabelas. Jakarta: Salemba Empat.

Simamora B. 2004. Panduan Riset Prilaku Konsumen. Jakarta: Gramedia Pustaka Utama.

Sulistiyani AT. 2004. Kemitraan dan Model-Model Pemberdayaan. Jogjakarta: Gala Media.

Sumarwan U. 2014. Metode Riset Bisnis dan Konsumen. Bogor: IPB Press.

Wahyuningsih R. 1999. The origins and impacts of public service in Indonesia Higher Education: Three Case Studies [desertasi]. New York: University of New York. 